Araştırma Makalesi

Research Article
Gönderim Tarihi/Submission Date: 10.05.2020

Kabul Tarihi/Accepted Date: 26.05.2020

DOI: $10.46250 /$ kulturder.735097

Kültür Araştırmaları Dergisi, 2020, Sayı: 5, s. 70-88.

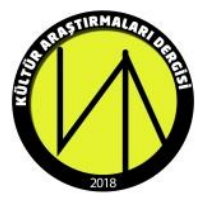

\title{
ÖMER SEYFETTIN'iN “YÜKSEK ÖKÇELER” VE “NAKARAT” HIKÂYELERINDE MIZAHI UNSURLAR VE AHLAKI BIR DEĞER OLARAK NAMUS
}

Humorous Factors and Honor as a Moral Value in Omar Seyfeddin's "High Heels" and "Chorus" Stories

Zeynep Nur TiRYAKi*

\section{ÖZET}

Türk edebiyatında hikâyenin önemli isimlerinden biri olan Ömer Seyfettin'in hikâyelerinde mizahi unsurlar yoğun olup onun hikâyelerinde ahlaki bir değer olarak namus kavramı da geniş bir yer tutmaktadır. Ömer Seyfettin'in hikâyeleri bu anlamda eleştirel bir ton taşımaktadır. Ömer Seyfettin'in "Yüksek Ökçeler" ve "Nakarat" hikâyeleri mizahi unsurlar taşımaları ve bireyler özelinde sosyal eleştiri yapmaları bakımından öğretici olmakla birlikte iki hikâyenin ortak noktaları mizah ve namustur. "Yüksek Ökçeler"i mizahi bir hikâye yapan unsurlar, "Nakarat"ta kara mizah/trajikomedi biçiminde yer almaktadır. ỉki hikâyenin bu bağlamda karşılaştırılması, Ömer Seyfettin'in mizahi yönünü ve bu mizahi yönün ne amaçla kullanıldığını açıklamaya olanak sağlayacaktır. Bu hikâyelerdeki namus kavramı ve bu kavramın işleniş biçimi; Ömer Seyfettin'in, hikâyelerinde ahlaki eğitimi nasıl öne çıkardığını anlamaya yardımcı olacaktır. Bu çalışmanın amacı, Ömer Seyfettin'in "Yüksek Ökçeler" ve "Nakarat" hikâyelerinden yola çıkarak yazarın toplumu eğitme/eleştirme amacıyla yahut safi olarak işlediği mizahi unsurları ve ahlaki bir değer olarak namus kavramını tespit etmektir. Ömer Seyfettin'in hikâyeciliği böylece, hikâyeciliğini oluşturan bu en mühim noktalar üzerinden aydınlatılmış olacaktır.

Anahtar Kelimeler: Modern Türk Edebiyatı, Mizah, Ahlak, Namus, Sosyal Eleştiri.

\section{ABSTRACT}

Humorous factors are abundant in Omar Seyfiddin's stories, who is an important personality of stories in Turkish literature, and honor as a moral value plays a significant role in his stories, too. Omar Seyfiddin's stories include a critical tone in this sense. As well as Omar Seyfiddin's "High Heels" and "Chorus" stories are didactic in terms of including humorous factors and making social criticism specific to individuals, common grounds of the two stories are humour and honor. The factors which make "High Heels" a humorous story, take place in "Chorus" in the shape of black humour/tragicomedy. Contrasting the two stories in this context

\footnotetext{
* Yüksek Lisans Öğrencisi. Marmara Üniversitesi, Türkiyat Araştırmaları Enstitüsü, Türk Dili ve Edebiyatı Anabilim Dalı-istanbul. E-posta: zeynepnurtiryaki@hotmail.com. ORCID ID: 00000002-3456-5224.
}

This article was checked by Turnitin. 
will enable to explain Omar Seyfiddin's humorous side, and for which purpose this humorous side was used. Honor concept and the treating style of this concept will help to understand how Omar Seyfiddin emphasized moral education in his stories. The purpose of this study is to determine humorous factors that the writer treated, on the purpose of educating/criticizing the society or in a simple way, and the concept of honor as a moral value by predicating on Omar Seyfiddin's 'High Heels" and "Chorus" stories. Thus, Omar Seyfiddin's story writing will be illuminated through these most essential points which compose his story writing.

Key Words: Modern Turkish Literature, Humour, Morals, Honor, Social Criticism.

\section{Giriş}

Türk edebiyatının önemli hikâyecilerinden biri olan Ömer Seyfettin, hikâye yazmaya, Fransızca öğrenip Fransız edebiyatını tanıdıktan sonra başlamış, Fransız edebiyatından beğendiği ilk yazar Guy de Maupassant'ın hikâyelerini "insana gerçeği öğrettiği, insanı gerçeğe görmeye ve düşünmeye alıştırdığı için” güzel bulmuştur (Önertoy, 1972: 138). Nitekim Ömer Seyfettin'in hikâyeciliğinde gerçeklik önemli bir yerdedir. O, gerçeği görür, analiz eder ve hikâyelerinde işler. Yazdıklarının formunun hikâye olması önemlidir: Servet-i Fünun'dan sonra en olgun tekniğe sahip hikâyeleri yazan ve küçük hikâyeyi bir yazarın başlı başına bağlanacağı bir edebî tür haline getiren Ömer Seyfettin olmuştur (Önertoy, 1972: 138).

Ömer Seyfettin'in hikâyelerinde mizahi unsurlar yoğun olup onun hikâyelerinde ahlaki bir değer olarak namus kavramı da geniş bir yer tutmaktadır. Ömer Seyfettin'in hikâyeleri bu anlamda eleştirel bir ton taşımaktadır. Ömer Seyfettin'in hikâyeleri, yazarın ele aldığı ağırlık noktasının "medenî seviyemizin yükselmesine engel olan sosyal aksaklıkların tasvir ve tenkidi" olduğunu göstermektedir, yazar bu tenkitlerinde ise mizahı tercih eder (Önertoy, 1972: 140). Ömer Seyfettin'in hikâyelerinde mizahı tercih etmesinin ipuçları Tahir Alangu (1968: 76) tarafından verilmiştir: "Ömer'in Harbiye hayatı bir dönüm noktasıdır. Burada geçen bir hâdisenin, onun şahsiyetini göstermesi bakımından, büyük değeri vardır bence. Bedenen de çok canlı olan Ömer Seyfettin, Edirne Askerî İdadi'sinin birinci sınıfına kadar çok afacan bir çocuk olduğu hâlde, hiç vukuât çıkarmamıştı." Buradaki ipuçları, yazarın "bedenen çok canlı olması" ve "afacan olması"dır. Yakup Kadri, Ömer Seyfettin'in zabitlik yılları için de aynını söyler: "Bu genç zâbit bilâ fâsıla neşeli, bilâ fâsıla şûh ve cevvâl, o fikirden bu fikire, bu bahisten o bahise atlar, ekseri meselelerde düşüncelerimiz birbirine uymadığı hâlde neticede yine bizimle müttefik kalırdı. Ne kadar mûnis, ne kadar hafif bir zekâsı vardı. En acâyip nazariyeler bile onun ağzında tabiileşir ve bizim çoktan inandığımız, bildiğimiz kanaâtler sırasında 
geçerdi..." (Alangu, 1968: 96). Buradan çıkarılacak sonuç, hikâyelerindeki mizahın yazarın kişisel hayatından yansıyan bir yöntem olmasıdır. Hikâyelerinde de bu canlılık, bu afacanlık vardır ve bilhassa "Yüksek Ökçeler"de en abartılı olaylar bile normalmiş gibi anlatılır. Nitekim Olcay Önertoy (1972: 140) da Ömer Seyfettin için "Yakın arkadaşlarının belirttiklerine göre Ömer Seyfettin, yaradılış itibarile, yaşamaktan derin bir zevk duyan, bedbinlik nedir bilmeyen, kederden kaçma çarelerini arayan bir tiptir. Sade yazarken değil, konuşurken de nükte yapmaktan ve hicvetmekten hoşlanır." demiş ve hikâyelerinde mizahın önemi ve kullanımını şu şekilde açıklamıştır: "Mizah unsuru, hikâyelerine iki fayda sağlamıştır. Bunlardan birincisi, hikâyelerinin daha ilgi çekici ve sevimli bir hâle gelmesi; ikincisi de, alay etmenin tenkit bakımından taşıdığı kuvvetli etkisinden faydalanarak tenkitlerinin daha etkili bir duruma gelmiş olmasıdır. 'Yüksek Ökçeler, Koç, Külâh, Nasıl Kurtarmış?, Çakmak' gibi hikâyeleri ise, sosyal tenkit amacı güdülmeden, doğrudan doğruya mizahla ilgili olarak yazılmıştır.” Bu bağlamda yazarın hikâyelerinde mizahı araştırmak ve açıklamak, onun hikâyeciliğinin önemli bir noktasını anlamayı beraberinde getirecektir.

Ömer Seyfettin'in hikâyelerindeki diğer önemli nokta, ahlaki değerleri işlemesidir. Yunus Emre Özsaray (2018: 403), Ömer Seyfettin'in hikâyelerindeki ahlaki kavramlara şu şekilde vurgu yapar: "insanın yeni bir hayat telakkisi etrafında zihniyet değişimi geçirmesi için hikâyeleriyle toplum eğitimi yolunu seçen Ömer Seyfettin'in hikâyelerine aynı zamanda bu değer değişiminin arızalı yanları da yansımıştır. Bilhassa yeni değerler karşısında yaşanan ahlâk bozgunu kimi hikâyelerinin konusu olmuştur." Yazarın hikâyelerinde ahlaki bir değer olarak görülen unsurlardan biri, namustur. Yazar, birçok hikâyesinde namus kavramına vurgu yapar. Yahya Kemal Beyitoğlu (2018: 51-52), Ömer Seyfettin'in hikâyelerindeki namus kavramını şöyle açıklar: “Ömer Seyfettin'in hikâyelerindeki ideal toplumun fertleri ahlaki değerlere sıkı bir şekilde bağlıdır. Özellikle namus, toplumun temel taşlarından birini teşkil eder. Bu fertler en zor şartlarda dahi bu değerden ödün vermezler."

Ömer Seyfettin'in "Yüksek Ökçeler" ve "Nakarat" hikâyeleri mizahi unsurlar taşımaları ve bireyler özelinde sosyal eleştiri yapmaları bakımından öğretici olmakla birlikte iki hikâyenin ortak noktaları mizah ve namustur. "Yüksek Ökçeler"i mizahi bir hikâye yapan unsurlar, "Nakarat"ta kara mizah/trajikomedi biçiminde yer almaktadır. iki hikâyenin bu bağlamda karşılaştırılması, Ömer Seyfettin'in mizahi yönünü ve bu mizahi yönün ne amaçla kullanıldığını açıklamaya olanak sağlayacaktır. Bu hikâyelerdeki namus kavramı ve bu kavramın işleniş biçimi, Ömer Seyfettin'in hikâyele- 
rinde ahlaki eğitimi nasıl öne çıkardığını anlamaya yardımcı olacaktır. Bu çalışmanın amacı, Ömer Seyfettin'in "Yüksek Ökçeler" ve "Nakarat" hikâyelerinden yola çıkarak yazarın toplumu eğitme/eleştirme amacıyla yahut safi olarak işlediği mizahi unsurları ve ahlaki bir değer olarak namus kavramını tespit etmektir. Ömer Seyfettin'in hikâyeciliği böylece, hikâyeciliğini oluşturan bu en mühim noktalar üzerinden aydınlatılmış olacaktır.

\section{1. "Yüksek Ökçeler" ve "Nakarat" Hikâyelerinde Mizah Unsurları}

Mizah; gerek hayatta gerekse sanat ve edebiyatta kullanımı itibarıyla yaşanan gerçekliğe farklı bir bakış açısıyla bakabilen, sorgularken gülümseten, gülümsetirken düşündüren, düşündürürken farklı noktalara dikkatleri çekebilen bir anlatım tarzıdır (Alay, 2019: 22). Mizahın tek kullanım biçimi güldürmek değildir, mizah aynı zamanda abartmak, hicvetmek, kötü bir durumu anlatmak biçiminde de kullanılabilir, yani mizahın toplumsal eleştiri boyutu da vardır. Nitekim Okan Alay (2019: 24), "Ferit Öngören gibi mizahın illa gülme ile bağlantılı görülmemesi gerektiğini savunan araştırmacılar da vardır." demiştir. Mizah, yaşanan olaylardan yola çıkarak bugünü bazen doğrudan bazen de dolaylı bir şekilde sunan, yorumlayan, olayların farklı yanlarını gözler önüne sererek geleceğe ışık tutan bir türdür (Çetinkaya, 2006: 4). Mizahi anlatımın özelliklerinden biri; sembol dilinin kullanılmasıdır, bastırılan bir duygu, düşünce veya isteğin yansıtılması sırasında bir sembolden yararlanılarak dolaylı olarak hedefe ulaşmaya çalışıır, yani mizah; engellenen ve düşüncelerini ifade edemeyen insanların bu ihtiyaçlarını gideren bir araçtır (Alay, 2019: 26). Ömer Seyfettin'in "Yüksek Ökçeler" hikâyesi, Elif Aktaş ve Serap Uzuner Yurt (2017: 210) tarafından mizahi hikâyelere dâhil edilmiştir. "Nakarat" hikâyesi ise doğrudan mizahi bir hikâye değildir, "Nakarat"। kara mizah olarak değerlendirmek gerekmektedir. Gülnaz Çetinkaya (2006: 7), kara mizah türünü şu şekilde açıklamaktadır: "Turhan Selçuk; 'Mizah (humor) yalnız güldürü değildir. Düşündüren, eleştiren, istihza eden, bir çeşit acı duygusu veren, hicveden, karşıt fikirleri kapsayan ve fikirleri beklenmedik, şaşırtıcı bir biçimde sunan türleri vardır. Kara mizah, pembe mizah deyimleri bu yüzden çıkmıştır.' şeklinde mizahın özellikleri ve türleri ile ilgili bilgiler vermektedir. (Selçuk, 1998)."

Ömer Seyfettin'in "Yüksek Ökçeler” hikâyesi, on üç yaşında altmış altı yaşında bir adamla evlendirilen, genç yaşta dul kalan, başlıca merakı temizlikle namusluluk olan, Göztepe'deki köşkünde evlatığı, hizmetçisi ve aşçısıyla yaşayan Hatice Hanım'ın hikâyesidir. Hatice Hanım'ın zihnindeki erkek, "romatizma, balgam, pamuk, vandoz, tentürdiyot yığınlarından yapılmış, pis, abus, lanet bir heyula şeklinde" (Galin, 1989: 102) mizahi 
biçimde tanımlanmaktadır. Bu tanımlamada hem gülünç (erkeğin yaşlanmanın bütün kötü yanlarıyla özdeşleştirilerek abartılması) hem de üzücü (Hatice Hanım'ın evliliği yüzünden anormal olanı normalleştirmesi) bir taraf vardır. Ömer Seyfettin, Hatice Hanım'ın şahsında o dönemde yapılan evliliklere ve evliliğe bakışa eleştirel bir bakış yöneltmektedir. Hatice Hanım'ın yaptığı evlilik yüzünden bütün erkeklere takındığı tavırda da yazıldığı dönemi ve bu dönemin yorumlanışını bulmak mümkündür. Nitekim mizahın özelliklerinden biri de yazıldığı dönemi yorumlamasıdır (Çetinkaya, 2006: 4). Fethi Gözler (Arşiv-1), bu konuya şu şekilde açıklık getirmektedir: "Kadının eşini seçme hakkı ile ilgili olarak Tanzimat'tan beri işlenen temaya Ömer Seyfettin de temas etmiştir. $O$ da evlenecek gençlerin birbirine uyan denklikte olmasını ister, özellikle genç kızların ihtiyar erkeklerle evlenmelerine karşı çıkar. Bu fikrini, Birdenbire, Devletin Menfaati Uğruna, Antiseptik, Nezle, Yüksek Ökçeler adlı hikâyelerinde etraflıca işlemiştir." Ömer Seyfettin, başlı başına farklı bir makale/tezin konusu olabilecek bu sosyolojik konuyu "Yüksek Ökçeler"in Hatice Hanım karakteri üzerinden mizahi bir şekilde -mübalağa yaparak- işlemektedir. Hatice Hanım'ın başlıca özelliklerinden biri olan temizlik merakı da mizahi bir unsur olarak okunabilir: "Göztepe'deki köşkünü hizmetçi Eleni ile, evlatlığı Gülter’le her sabah beraber temizler, aşçısı Mehmet'i her gün tıraş ettirir, zavallı Bolu'lu oğlanı tepeden tırnağa kadar beyazlar giymeye mecbur ederdi." (Galin, 1989: 102). Hatice Hanım'daki temizlik merakının abartılı derecede işlenmesi, bu unsuru mizahi kılmaktadır. Mehmet'in "zavalı" diye nitelenmesi, Hatice Hanım'ın abartılı derecede takıntılı yönüne işaret etmektedir. Hatice Hanım'ın abartılı ve mizahi olarak çizilen diğer bir yanı, evinde bulunan kişilere kimseyle görüşmemelerini salık vermesidir: "Benim gibi olun! Ben kimse ile görüşüyor muyum? Sakın siz de komşuların hizmetçileriyle, uşaklarıyla konuşmayın. El insanı azdııı!” (Galin, 1989: 102). Namusluluğu sağlamak için hizmetçilerinin kimseyle görüşmesini istemeyen ve kendisi de kimseyle görüşmeyen Hatice Hanım'ın gayet tabii olan iletişimi karalaması absürt ve gülünç bir olaydır. Hikâyede abartıyla sağlanan mizahi unsurlardan biri de Mehmet'in arka bahçedeki mutfağına yabancı bir kedinin dahi girmemesidir.

Ömer Seyfettin, Hatice Hanım'ı "güzel, tombul ve cıvıl cıvıl bir şey” (Galin, 1989: 102) olarak tasvir ederken diğer bir takıntısının altını çizer: Yüksek ökçeler. Hatice Hanım, evrensel güzellik anlayışında daha çok yer edinmiş olan uzun boya ulaşmak için köşkünün içinde yüksek ökçeli iskarpinleri giymektedir: "Fakat boyu çok kısa olduğu için evin içinde de, bir karışa yakın ökçeli iskarpinler giyerdi. Adeta bir cambaza dönmüştü." (Galin, 1989: 102). "Yüksek Ökçeler” in başlıca mizah unsuru budur. Ömer 
Seyfettin, Hatice Hanım'ı yüksek ökçeli iskarpinleriyle adeta bir cambaza dönüştürerek gülünçleştirmektedir. Hanımın yüksek ökçelerinden dolayı hasta olması ve yumuşak terlikler giydikten sonra tamamen iyileşmesi de absürt ve gülünçtür. Evden çıkmadığı, başkalarıyla görüşmeyi namussuzluk saydığı ve evinde süslenme adına yüksek ökçeler giydiği için Hatice Hanım, kendini "saçma" bir hale sokmuş ve bu saçma ve gülünç (cambaz) hali yüzünden doktora gidecek kadar hasta olmuştur. Hatice Hanım'ın gerçek hayatta çok zor rastlanılacak derecede abartılarak okuyucunun dikkatine sunulması, "Yüksek Ökçeler" hikâyesini son derece mizahi kılmaktadır. Hatice Hanım'ın dokuz senelik hizmetçilerinin iki gün içinde ahlaklarının bozulması, tamamen absürt bir durum ve ironi yönüyle mizahi bir unsurdur, hikâye bu ana mizah unsuru etrafında şekillenir. Ömer Seyfettin, Hanım'ın ses çıkarmayan yumuşak terlikler giymeye başlamasıyla iki gün içinde değişen insanlar arasında alaycı bir bağ kurup okuyucuyu şaşırtmaktadır. Hatice Hanım'ın karşılaştığı hırsızlık ve namussuzluklardan sonra her tarafı kilit altına alması, hikâyeyi daha da mizahi kılmaktadır. Köşkte çalınacak hiçbir şey kalmayınca hizmetçilerin hırsızlık yapamadıkları için ahlaksızlık yapmaya devam etmeleri Ömer Seyfettin'in alaycılığını yansıtmaktadır: "Ülen Gülter, artık sen şeker filan getirmeyon?, Ülen, gece niçin gelmiyon? Sana halva yapıp saklayom!, Yakalanazağız vire! Sonra Hanım bizi kovazak!” (Galin, 1989: 103). Ömer Seyfettin, sadece olay örgüsünde değil, dil hususunda da mizahı kullanmaktadır, dilde halk ağzının kullanılması mizahi bir unsurdur. Erol Tanrıbuyurdu (2007: 104), bu konuya şu şekilde açıklık getirmiştir: "Tarih boyunca gülme ve ciddi olma durumu soylularla halk arasında keskin bir sınır çizgisi gibi durmuş, ciddiyet soylular, devlet ve devletin kurumlarl; komedi ve komik ise halkla ilişkilendirilmiştir." Alay'a göre (2019: 24) mizah, başlı başına bir tür olmaktan öte; bir ifade biçimi, anlatım tarzı, bir üslup özelliğidir. Mehmet'in "tuhaf bir şapırtı" içinde olması, üçlünün aralarında "çıtır pıtır bir hasbihal"e başlamaları da dilin mizahi kullanımını yansıtmaktadır.

Mizahın zaferi, hakikatin öteki yüzüyle de yüzleşmek demektir, mizah, bu özelliğiyle yaşanan gerçeklikten esinlenerek onu yeniden yorumlayıp komiğin dikkat çekiciliğiyle aktarır (Alay, 2019: 22). Hatice Hanım'ın yüzleştiği hakikatin öteki yüzü, yüksek ökçelerin, kızdığı ahlaksızlıkları örten bir sembol görevi görmesidir. Gülter'in sözleri bu mizahi unsuru daha da ön plana çıkarmaktadır: "Ah o terlikler! Her işimizi bozdu. Hanımın geldiği hiç duyulmuyor. Ne yapsak yakalanıyoruz. Eskiden ne iyiydi. Yüksek ökçelerin takırtısından evin en üst katında kımıldandığını duyardık." (Galin, 1989: 103). ỉki gün içerisinde gerçek yüzleri açığa çıkan hizmetçilerin yaptıklarından pişman olmamaları, hatta yaptıkları şeyin terlikler yüzünden "bo- 
zulduğunu" söylemeleri; Ömer Seyfettin'in hırsız, namussuz, alçak insanlara karşı takındığı eleştirel tutumu yansıtmaktadır. Mizahi anlatımda; "Yapısal bir ilişki, çağrışım, anlaşma, rastlantısal benzerlik vb. yollarla başka bir şeyi temsil eden, onun varlığına işaret eden bir nesne, figür, imaj, mimik, eylem, olay, ses, harf, kelime, işaret.” (Budak, 2000: 462) sembolleştirilerek ima yoluyla amaca ulaşma eğilimi vardır (Alay, 2019: 26-27). Yüksek ökçeler de bu anlatıda, mizahi anlatımın dayandırıldığı yegâne nesnedir ve gerçekliği örten bir perde konumundadır. Hatice Hanım; iki sene boyunca eve aldığı hizmetçilerden daima ahlaksızık ve namussuzluk görmeye devam edince tekrar başı dönmeye başladığı halde yüksek ökçeleri giymeye devam edip ruhi azap çekmemek için orada olduğunu bildiği hakikatin öteki yüzünü kapatmış, "Hiç olmazsa yüreğim rahat ya..." (Galin, 1989: 104) diyerek teselli bulmuştur. Tüm olup bitenler ahlaki çöküşü, değerlerin altüst oluşunu göstermektedir. Hatice Hanım'ın sonunda buna teslim olması ise Ömer Seyfettin'in ruhi mutluluğu öne çıkardığını gösterdiği gibi okurda bir acıma uyandırır. Burada da komik olmayan bir şeyin mizahı söz konusudur.

"Nakarat" hikâyesi, "Gençliğini Makedonya'da geçirmiş eski bir subayın hatıra defterinden" başlığını taşımaktadır (Seyfettin, 2009: 54). İnci Enginün, Ömer Seyfettin'in bu hikâyede yıkılış halindeki Osmanlı devletinin mozayık yapısında Türklük için yegâne kurtuluş yolu olarak gördüğü Türklük şuurunun uyanışını anlattığını belirtir (Arşiv-2). "Yüksek Ökçeler" ile "Nakarat"ı mizah bakımından ayıran nokta, hikâyelerdeki mizahın farklı türlerde olmasıdır. "Nakarat", Ömer Seyfettin'in "Balkan coğrafyasındaki karışıklıklardan, Balkan savaşlarından, Balkan kavimlerinin bu savaşlar sırasında Türklere uyguladıkları zulüm ve işkencelerden söz eden hikâyeleri arasında yer alması" (Barış, 2016: 36) hasebiyle ideolojik bir bağlama sahiptir. Ömer Seyfettin, bu hikâyede Bulgarların Türklere olan nefret dolu bakışlarına dikkat çekip Bulgarların çoğunda olan bu bakışın olumlu hale gelmesinin çok zor olduğunu savunur (Güneş, 2011: 173) çünkü milliyetçilik düşüncesinin etkisinde kalan Balkan kavimleri Avrupa devletlerinin de desteğini alarak Rumeli coğrafyasını Türklerden arındırmak ve bu coğrafyadan Türk kültür ve kimliğini silmek istemektedirler (Güneş, 2011: 184). Bu hikâyede Türklük idealinin başkalarının/karşı kültürlerin üzerinden hatırlandığını söyleyen Beyhan Kanter (2013: 102), hikâyedeki başlıca mizah unsurunun -kara mizahın- altını çizmiş olmaktadır. "Yüksek Ökçeler” güldürücü bir mizah taşırken "Nakarat", kendi değerlerini unuttuğu için Ömer Seyfettin tarafından eleştirilen bir subayın "acı" mizahıdır. Nitekim Abdullah Şengül (2001: 12) de, bunu şu şekilde dillendirir: "Aynı buruk mizah, 
anlatıcı kahraman bakış açısıyla kaleme aldığı Nakarat isimli hikâyesinde de vardır."

"Nakarat", hikâyenin başkahramanı olan subayın hayal ettiği gerçeklik ile içinde bulunduğu gerçeklik arasındaki tezadı yansıtarak başlar. Genç subay, içinde bulunduğu durumdan mutlu değildir ve hayale benzeyen bir hakikat bulursa mutlu olacağına inanır. Ömer Seyfettin, genç subayın acı mizahını onu farklı kılarak vurgulayacaktır: "Arkadaşlarımın hepsi memnun... Yalnız ben üzgün! Neden? Bu sefaletten, bu perişanlıktan! Ben mükemmel, düzenli, şık bir ordu istiyorum." (Seyfettin, 2009: 55). Subay, ideolojik bağlamda, arkadaşları gibi vatani görevini içtenlikle yapmadığından mutsuzdur. Hikâyedeki kara mizah, bu tasvirlerle başlar. Ömer Seyfettin, bir Türk subayının görevinden uzak oluşunu subayı acınası bir hale sokarak eleştirir. Dil hususunda da mizahi unsurlar görülmektedir: "Agâh Usta, Karagöz gibi başını içeri uzattı." (Seyfettin, 2009: 56).

Subay, birbirine benzeyen boş günlerden bıkıp tayinini istediğinde Velmefçe taraflarına gönderilmiş ve burada da aynı korkunç duygular peşini bırakmamıştır: "Bulunduğum yer, benliğim, şimdi bana yanlış bir hayal, korkunç bir serap, karanlık bir kâbus geliyor. İsim verilemez bir acı duyuyorum. Sanki bir kabir azabı..." (Seyfettin, 2009: 58). Subayın vatanı için bulunduğu yerdeki mutsuzluğu, Ömer Seyfettin'in alaycılığıyla birleşerek abartıır. Bu, mizahi bir unsurdur. Subayın altı aydır ilk defa bir güzel görmenin sevinciyle ona doya doya bakması ve bütün boş zamanlarında pencereye çıkarak içinde bulunduğu durumdan dolayı çektiği azabı yatıştırması, canlanması ve hatta gördüğü Balkan kızına olan aşkından merkeze yazarak onu bulunduğu yerden çekmemelerini istemesi, Ömer Seyfettin'in alaycılığıyla yansıtılır. Vatani vazifesini yerine getirmesi gereken subayın içinde bulunduğu halden azap duyması ve bir anda bütün yaşam sevincini bir Bulgar kızına bağlaması, ironik ve abartılı bir mizah unsurudur. Subaya göre yaşadığı bu hal, "taraçadaki güzel, iri, şen kızla uzaktan bir sevişme"dir (Seyfettin, 2009: 61). Subayın, gördüğü bu kızla uzaklara, Amerika'ya kaçmak istemesi, onunla başka hayatlar, başka ufuklar hayal etmesi, vatani görev bilincinden ne kadar uzak olduğunun en çarpıcı örneklerinden biridir. Beyhan Kanter (2013: 103), subayın uzaktan görüp âşık olduğu Bulgar kızıyla Amerika'ya kaçma düşüncesini "kayıtlardan, sorumluluklardan kurtulmaya yönelik bencil bir tutumun dişa vurumu" olarak değerlendirir. Amerika, Ömer Seyfettin'in savaş yıllarında yazdığı birçok hikâyesinde huzur ve mutluluğun ülkesi olarak tasvir edilmiştir (Koçak, 2015: 640). "Bomba" hikâyesinde Boris de Amerika'ya kaçmak ister ve yazar, Makedonya'nın o tarihlerde insanî muamele, güven ve huzurdan 
yoksun olduğunu vurgulamak için Amerika'yı idealize eder (Güneş, 2011: 29). Subayın arzusu hep kaçmak yönündedir: "Hep arzum kaçmak, kayıtlardan kurtulmak, vatanı, aileyi, ebediyen terk etmek!" (Seyfettin, 2009: 62). Subay, "bir Bulgar kızı kaçırarak dertler içinde bocalayan zavallı devletin başına yeni bir problem açmak" istemediğini söylese de asıl arzusu bu yöndedir. Bu, ironik bir mizah unsurudur. Ömer Seyfettin, bu açıdan subaya oldukça eleştirel bir bakış yöneltir. Subayın iç konuşmaları "Nakarat"ın temel eleştirel noktalarından birini oluşturur: "iş görecek, vatana hizmet edecek çağımda, orduyu bırakmak, ateşten, çatışmadan, harpten kaçmak! Artık tabii kurşuna dizilmemek, yahut bir alçak gibi hapishanelerde sürünmemek, hakarete uğramamak için memleketime de dönmeyeceğim. Sevgili annem gözyaşları içinde benim hayalimi arayarak ölecek. Babam akrabalarına, dostlarına karşı benim hıyanetimden utanacak. Kimsenin yüzüne bakamayacak." (Seyfettin, 2009: 62). "Nakarat"taki eleştiriler, Ömer Seyfettin'in bu hikâyede ideolojik bir bağlamda işlediği mizahın temelini oluşturması bakımından oldukça önemlidir.

Subayın âşık olduğu Bulgar kızı Rada, devamlı şu nakaratı söylemektedir: "Naş, naş/Çarigrad naş.../Raz-dva-tri". Subaya göre bu nakarat, aşklarının bestesidir: "Naş’ların öyle tutkulu, öyle canlı, öyle âşık, öyle kızgın bir uzanışı var ki... Ruhtan daha derin bir yerden geliyor." (Seyfettin, 2009: 65). Subay, bu şarkının ezberleyemediği diğer kıtalarında "Balkan, Şıpka, Marista" kelimelerini duyduğu halde bunu aşk bestesi olarak görecek kadar safderundur. Gerçekte anlamı "Bizim olacak/istanbul bizim olacak" olan nakarat, subayın gözünde "Seni çok seviyorum/Seni çok seviyorum" anlamındadır. Genç subayın Bulgar kızına eşlik ederek "Şehvet dolu bir aşk Eflatunîlik!” (Seyfettin, 2009: 67) olarak tanımladığı aşk, gerçekte subaya karşı düşmanca bir tavırdır. Ömer Seyfettin, hayal ile hakikat zıtlığını ustaca işleyerek subayla alay eder ve vatani görev konusunda bu genç subay gibi olanların da aynı sonla karşılaşmaya mahkûm olduğunu söylemek ister. Üstelik subay, Rada'ya sürpriz yapmak maksadıyla onun söylediği nakaratı kendisi de söylemiş ve kızın "Bravo!" nidalarıyla karşılanmıştır. Bu da Bulgar kızı Rada'nın, Bulgarlar karşısında temsil ettiği Türk milletini küçük düşüren bu genç subayla alay ettiğini göstermektedir. Subayın hediye olarak göndereceği kolonya şişesini Rada'ya iletmesi için verdiği çocuk bile onun bu haline gülmüştür. Bu gülüşe, hem Ömer Seyfettin'in bu hale gülmesi anlamında hem de mizahi bir unsur olarak bakmak mümkündür. Ömer Seyfettin'in mizahi bir unsur olan ironiyi kullanarak söylemek istediği, Türklüğün değerlerine göre hareket ederek gülünç durumlara düşmemek gerektiğidir. 
Ömer Seyfettin, nakaratın anlamını öğrenen subayın kötü sonunu şu şekilde vurgular: "Insan olmadığımı, hayvandan farksız bir budala, bir ahmak, bir sefil olduğumu birdenbire anlamak... Öldürüp de yaşar bırakan bir cehennem yıldırımı gibi beni yere serdi." (Seyfettin, 2009: 70). Subay, Rada'nın "kendince mukaddes bir fikir için ölen" babasıyla arasındaki farkı sorgulayarak sonunda vatani görevini başkaları üzerinden hatırlamaktadır. Okan Alay (2019: 24), "Mizahçı da tıpkı nükteci gibi bir şeyle, biriyle ya da herkesle alay etmek ister; fakat belirtmeye çalıştığı gülünç yan güldürmek amacını gütmüyor gibi görünmelidir. Hem söylediği vardır burada hem düşündüğü..." diyerek mizah ve alay ilişkisine değinir. Ömer Seyfettin'in de burada kara mizahla düşündürdüğü şey, vatani görevden ve Türklük bilincinden uzak olmanın ne kadar ahmakça olduğudur. Subayın ideal olandan ne kadar uzak olduğunu ve sadece maddi şeylerin peşinden koştuğunu Ömer Seyfettin şöyle dile getirir: "Erkânıharp olmak bütün gençliğimi dolduran bir hırstı. Niçin? Yazacağım işte... Çabuk terfi etmek, yüksek mevkilere geçmek, güzel İstanbul'da zevk içinde, eğlence içinde yaşamak, çok iyi yemek, çok iyi içmek, çok iyi giyinmek, zengin bir hanım avlamak, çabucacık paşa olmak, Avrupa'da ateşemiliterlikle keyif yetiştirerek, ömür sürmek için değil mi? Evet, işte hep bunlar için!” (Seyfettin, 2009: 71). Ömer Seyfettin, bu subay üzerinden devrinin eleştirisini de yapmaktadır. Okan Alay'a göre (2019: 27) mizah, ait olduğu toplumun kültürel dinamikleriyle bir gelenek çerçevesinde gelişerek ilerleme kaydetmiş ve her bir dönemde içinden çıktığı toplumun âdeta aynası olmuştur. Dolayısıyla onda toplumun sosyal, kültürel, siyasi ve ekonomik yapısını gösteren değerler bir aradadır ve bunların ortaya çıkarılmasıyla temsil edilen toplumun kimliğini görmek mümkündür. Aynı şekilde bu hikâyede de Ömer Seyfettin, mizah yoluyla yaşadığı çağı yansıtmıştır. Subayın "zavallı" nitelemesi, Osmanlı Devleti yeniden güçlü bir devlet haline gelmek için hastalığına çeşitli fikirlerle çare bulmaya çalıştığı içindir. Ömer Seyfettin, bu çeşitli fikirler içinde Türkçülüğü savunur ve dolayısıyla bu hikâyede Türklük bilincinden uzak olanlarla alay eder. Ömer Seyfettin'e göre bir kimse vatani vazifesini hakkıyla yerine getirmeli ve içinde bulunduğu toplumun değerlerine göre hareket etmelidir. Mehmet Narlı (2007: 107), "Nakarat"ın kara mizah kullanarak hedeflediği şeyi şu şekilde dile getirir: "Okur, 'Çarigrad naş'ın ne olduğunu anlar anlamaz, subayın safredunluğuna acıyla güler. Onun trajik kavrayışına hem üzülür hem de onu kınar. Ömer Seyfettin'in istediği de budur." Narlı'ya göre Ömer Seyfettin bu hikâyede, milliyetçilik ve bağımsızlık hareketlerinin içinde yaşadığı halde kendi durumunu kavramayan bir insanın ancak ahmak ve safderun olduğunu söylemek ister. 


\section{2. "Yüksek Ökçeler" ve "Nakarat" Adlı Hikâyelerde Ahlaki Bir Değer Olarak Namus}

Ömer Seyfettin, hikâyelerinde ahlaki değerleri ön plana çıkararak toplumu eğitmeyi amaçlar. Ömer Seyfettin'le ilgili kayıtlar, onun bu özelliğinin kendi kişiliğinden yansıdığını göstermektedir: "Bütün gücünü sosyâl tenkide yönelttiği hikâyelerinde psikolojik bir derinlik bulunmamakla beraber, karakter yaratmada büyük bir yeteneğe sahip olduğu muhakkaktır. Hikâye kahramanlarının bazılarında kendi karakterini vermeye çalışmıştır. 'Penbe Incili Kaftan' hikâyesinin kahramanı olan Muhsin Çelebi'nin karakterini belirtmek için yazdığı aşağıdaki satırlar, kendi izzet-i nefsine düşkün, başkalarınınkine de aynı derecede saygı gösteren kişiliğinin tasvirinden ibarettir. 'Namusuyle yaşar, kimseye eyvallah etmezdi..." (Önertoy, 1972: 140-141). Namus, sözlükte "Bir toplum içinde ahlak kurallarına ve toplumsal değerlere bağlılı, iffet ve dürüstlük, doğruluk" (URL-1) şeklinde tanımlanmaktadır. Namus vurgusu, Ömer Seyfettin'in toplumsal eğitiminin kilit noktalarından birini oluşturur. Ona göre ideal toplum, namuslu olmalıdır. Ömer Seyfettin için namuslu, ahlaklı, vicdan sahibi, asil, cesur, düşünen, kendine soru sorabilen kişi; güzel bir geleceğe sahiptir (Er, 2019: 205).

Ömer Seyfettin, "Yüksek Ökçeler" ve "Nakarat”ta da vurguladığı gibi, toplumun ahlakının bozulduğunu düşünür ve gerçek sanatçının fikirlerini eserlerinde işleyerek topluma aktardığına inanır. İnci Enginün (Arşiv-2), Ömer Seyfettin'in Ali Canip'e yazdığı mektuptan bu düşüncelerin dışa vurumuyla ilgili şu kesiti aktarır: "Ahlakî ve ruhî sukuttan şüphesiz hepimiz hissemizi almışız. Gel artık, aramızda vefa, mefkureye sadakat, kerem ve fedakârlık gibi faziletleri aramayalım. Gene eskisi gibi kendimce, şahsî olalım. Birer köşeye çekilerek çalışalım. Lisan hakkındaki mefkûremizi gölgede, uzaklarda, tenha yerlerde husule getireceğimiz büyük eserlerde halka kabul ettirelim. Yani hakiki sanatkâr olalım." Ömer Seyfettin, ahlaki bir değer olarak namusun ideolojiyle olan bağını da önemser. Namus kavramı, onda büyük bir ideale bağlıdır aynı zamanda: Türklük düşüncesi ile çökmekte olan vatanı kurtarmak. Nitekim namus kavramına birçok hikâyesinde değinmesi, onun bu kavrama ne denli önem verdiğini göstermektedir (Tulgar, 2019: 43-341): "Beyaz Lale", "Diyet", "Yalnız Efe", "Namus", "Yemin", "Uçurumun Kenarında", "Mahcupluk Imtihanı", "Birdenbire”, "Çirkin Bir Hakikat”, “Ölüm”, "Salon Eğlenceleri”.

"Yüksek Ökçeler”in başkahramanı Hatice Hanım'ın başlıca merakı temizlikle namusluluktur. Hatice Hanım, kendisi namuslu olduğu gibi çevresindekilerin de namuslu olmasını ister: "Eleni de, Gülter de son derece 
namusluydular. Kileri kitlemezdi, paraları meydanda dururdu. Hele Mehmet'in namusuna diyecek yoktu. Konuşurken gözlerini kaldırıp insanın yüzüne bile bakmazdı. Hatice Hanım, köşkten hiçbir yere çıkmadığı için işi gücü adamlarını teftişti." (Galin, 1989: 102). Hatice Hanım, onları sürekli olarak teftiş etmek bir yana, yabancıların onları azdıracağı düşüncesiyle onların da kendisi gibi hiç kimseyle görüşmemelerini buyurur çünkü başkaları namuslarını kirletebilir. "Ahlaki değerlere olan bağlılı", yani namus, bu hikâyede başkalarının malını gasp etmemek, kişisel hak ve özgürlüklere saygılı olmak, hırsızlık yapmamak, küfürlü konuşmamak, meşru daire dışında hiçbir kadın ya da erkekle münasebet içine girmemek, hele yabancılarla hiç konuşmamak biçiminde yansıtılmıştır. Mehmet'in başını kaldırıp Hanım'a bakmaması da meşru daire dışında hiçbir kadın ya da erkekle münasebet içine girmemek çerçevesinde değerlendirilmelidir. Hanım'ın köşkündekilere kimseyle görüşmemeleri konusunda yaptığı uyarı, Mehmet tarafından "bile" tutulmaktadır. "Bile" vurgusu dikkat çekicidir ve Ömer Seyfettin'in namus kavramını kadınlar için daha gerekli bulduğunu düşündürür.

Hatice Hanım'da baş dönmesine ve dizlerinde, baldırlarında sızıya neden olan yüksek ökçelerin doktorun tavsiyesiyle yerini yumuşak terliklere bırakması; dokuz senelik çalışanlarının iki gün içinde ahlaklarının bozulduğuna şahit olmasına sebep olarak Hatice Hanım'ın gözündeki “namuslu çalışanlar" algısını yıkar. Eleni'yi kendi diş fırçasıyla ağzını yıkarken görmesi kişisel temizlik ve kişisel mülke duyulan saygısızlığa, Gülter’i kilerde reçel kavanozunu boşaltırken görmesi ve keza Mehmet'i et günü olmadığı halde bol bir sahan külbastıyı yerken yakalaması arkadan iş çevirmeye ve hatta bir nevi hırsızlığa ve açgözlülüğe delalettir. Hatice Hanım'ın kuralları ve ahlak anlayışı oldukça sıkıdır ve günden güne namus anlayışına ters olan birçok ahlaksızlık ve namussuzluğa şahit olur. Mehmet'in komşu Paşa'nın neferleriyle koca bir lenger pirinç pilavını atıştırarak yabancılarla görüşmeme, hırsızlık yapmama, açgözlü olmama gibi kuralları çiğnemesiyle her tarafı kilit altına alarak bu ahlaksızlıkları engellemek ister. Hanım'ın kapının aralığından hizmetçilerini gördüğü kısım ise Ömer Seyfettin'in hikâyede namus kavramının yoksunluğunu en çok öne çıkardığı kısımdır: "Mehmet, ocağın başında kısa iskemleye çökmüş, bir dizine Eleni'yi, bir dizine Gülter'i oturtmuş; kalın kollarını ikisinin bellerine halattan bir kemer gibi sarmıştı. Hatice Hanım, bu levhanın rezaletini görmemek için hemen gözlerini kapadı. Fakat kulaklarının kapağı olmadığı için, konuştuklarını duymamazlık edemedi." (Galin, 1989: 103). Hanım, bu sırada Gülter'in Mehmet'e şeker çalıp getirdiğini ve Eleni'nin gece Mehmet'in yanına gittiğini, Mehmet'inse ona helva yapıp sakladığını işitir. Hanım'ın 
gördükleri karşısında gözlerini kapaması ise namus ilkelerine ne kadar sadık olduğunun kanıtıdır. Namussuzluğu görmeye bile dayanamaz. Elif Aktaş ve Serap Uzuner Yurt (2017: 217), bu hikâyede "cinsellik", "olumsuz örnek" ve "argo, kaba ve küfürlü sözcük" başlıkları altında tespit edilen unsurlara dikkat çekmiştir. Nitekim bu sahnede namusluluğa ters düşen bu üç şey de vardır. Hatice Hanım'ın köşkteki çalışanları bu sahnede namuslu olmanın bütün ilkelerine aykırı davranışlar sergilemişlerdir: Şeker hırsızlığı, bir erkeğin iki kadın ile birden yakın münasebet içine girmesi ve yine bu çerçevede bir kadının gece vakti bir erkekle gizli gizli buluşması, kaba konuşmalar (Ülen). Yüksek ökçeler, sesiyle o vakte kadar yapılan her türlü namussuzluğu gizleyen bir nesne konumundadır. $O$ anda ise yumuşak terlikler hiçbir namussuzluğu örtememektedir. Hizmetçilerin yüksek ökçelerin tıkırtısıyla yaptıkları şeyi gizlemeleri, doğruluk ve dürüstlük de demek olan namustan ne kadar uzak olduklarını gösterir. Hanım, bu riyakârlığa ve namussuzluğa, hizmetçilerini kovarak oldukça sert bir tepki vermiştir.

Hatice Hanım, sonraki iki sene boyunca evine kimi aldıysa hepsi arsız, hırsız, yüzsüz ve namussuz çıkmaktadır ve Hatice Hanım malı mülkü varken, hiçbir sıkıntısı yokken, hizmetçilerine üzülmekten zayıflamakta ve sararıp solmaktadır. "Hatice Hanım'ın bir çiçek, bir gül gibi gitgide sararıp solması; yalana dolana, namertliğe, ahlaksızlığa tahammül edemeyen insanların alçak, hırsız ve namussuz insanlar yüzünden heba olduğunun bir örneğidir." (Er, 2019: 216). Hatice Hanım'ın, bütün bu namussuzluklar karşısında duyduğu azaptan dolayı yüksek ökçelerini yeniden giymesi ve tekrar başı dönmeye başlasa bile onları giymeyi bırakmaması, bilinçli bir seçimdir. Hatice Hanım, yaşandığını bildiği türlü namussuzluk ve yolsuzluğa bakmamayı tercih etmiştir. Hikâyenin namuslu olarak çizilen tek karakteri Hatice Hanım, tek başına bütün bunları değiştirememektedir ve çaresizdir. Ömer Seyfettin, namus ilkelerine uymayan çoğunluğu, yani devrinin insanını en çarpıcı biçimde ortaya koymuş ve onlara ciddi bir eleştiri yöneltmiştir. Hikâye, doğrudan doğruya mizahla ilgili olarak yazılsa da sosyal aksaklıkları yansıtması bakımından önemlidir. Ömer Seyfettin; ikiyüzlü, yalancı, menfaatçi, riyakâr insanların sayısının artmasını "Yüksek Ökçeler" öyküsündeki Hatice Hanım'ın 'aşçı, işçi, artık eve ne kadar adam aldıysa hepsinin arsız, hırsız, yüzsüz, namussuz çıkması, tam iki sene bir adam akıllısına rast gelmeyişi' ile vurgulamaktadır (Er, 2019: 216).

3 Ekim 1918 tarihinde "Yeni Mecmua"da yayımlanan (Barış, 2016: 36) "Nakarat", namus kavramını toplumsal kimlikle ilişkilendirmektedir. "Nakarat"; Perlibeçe, Babina, Velmefçe gibi yazarın asker olarak bulunduğu 
bölgelerde geçer ve bölgede en büyük sıkıntı komitacılardır, komitacılar tarafından bölge halkı sürekli zulüm ve baskı altındadır (Koçak, 2015: 646). Koçak (2015: 646); Enginün'ün, Ömer Seyfettin'in kuvvetli milli şuura sahip olmasının kaynağını, bir asker olarak devletin tehlikede olduğu gerçeğini bilhassa Bulgarlar arasında iken gördüğü Rumeli'ye dayandırdığını belirtir. Bu hikâyede, genç subay milli kimlik bilincinden çok uzak bir haldedir. Askerlik hayatını "çapkın, neşeli ve gamsız" şekliyle hayal etmiştir (Seyfettin, 2009: 54-55). "Nakarat”ta namus kavramı, genç subayın milli değerlere uzak oluşu üzerinden verilmektedir. "Ömer Seyfettin, 'Ahlâk Bozgunu' isimli yazısında milletin ruhunda kökleşmiş akidelerin, dimağlara iman olan değerlerin bir bir eridiğinden bahsederken milletin ahlâkının kahramanlık, vatan, fedakârlık gibi birtakım değerlerle yeniden örgütlenmesi gerektiğinden, bunun için de bu değerleri harekete geçirecek bir ideal kişiliğin belirmesinden bahsetmiştir (Özsaray, 2018: 403-404)." Genç subay; "kahramanlık, vatan ve fedakârlık" gibi değerlere sahip olmadığından namusuyla ilgili çalkantılar yaşamakta ve kendinden utanmaktadır. Subayın kimliği, Ömer Seyfettin'in ideal olarak çizdiği kimliğin tam zıddıdır. Ömer Seyfettin, bu yüzden, subayın kimliğinde Türk milletinin bu acı ve gülünç hallere düşmemesi için bu ahlaki değerlere sahip olması gerektiğinin altını çizmektedir.

Arkadaşlarının aksine bulunduğu halden memnun olmayan ve hayalin tam zıddı olan hakikatin -çapkın, neşeli, gamsız askerlik hayatı hayal; soğuk, sıkıntılı ve bunaltıcı bir askerlik hayatı hakikattir- ağırlığı altında ezilen subay, taburun tüfekçisi Agâh Efendi'nin sadece eğlenmek, düşünmemek, ìstanbul'u büsbütün unutmak yolundaki nasihatlerini tutmaya çalışır. Bu nasihatler, Ömer Seyfettin'e göre toplumun bütünleşmesi gereken "vatan, kahramanlık" gibi değerlerle bağdaşmamaktadır. Bu anlamda Ömer Seyfettin'in toplum ahlakını sağlamak açısından subay ile birlikte Agâh Efendi'nin de eleştirisini yaptığını söylemek mümkündür. Burada aynı zamanda subayın içinde bulunduğu durumdan memnun olmaması paralelinde Ömer Seyfettin'in vatan, kahramanlık gibi değerlere sahip olmayanların mutlaka acı çekeceklerini anlatmak istediği düşünülebilir. Yani toplum ahlakına ters davrananlar, kendilerine zarar vermiş oldukları gibi, içinde bulundukları toplumu da küçük düşürürler. Namus kavramı subayın aklına ancak Velmefçe'de Bulgar kızı Rada'ya rastlayışından sonra düşer:

"Taraçadaki güzel, iri, şen kızla uzaktan bir sevişme! Onun ismini bile bilmiyorum. Dükkân sahibine, çırağına da soramadım. Hem sorsam ne fayda? Onu bilmem, fakat birtakım kayıtlar beni sımsıkı bağlamış. 
Harb Okulu'nun ikinci sınıfında "Ceza Kanunu” okutan bir hocamız vardı.

'Faziletli olmak insanın elinde değildir. Fakat kim isterse namuslu olabilir. Bu, tercihe bağlı bir şeydir!' demişti.

Onun düşüncesine göre kim gizli yaptığı şeyi açıkça yapıyormuş farz ederek Ceza Kanunnamesi'nin maddelerini hatırlarsa namussuz olmasına imkân yoktu. Lakin fazilet içeriden gelen bir şeydi. Buna zorla sahip olmaya çalışmak "ikiyüzlülük" olurdu." (Seyfettin, 2009: 6162).

Subay, hiç fazilet sahibi olmadığını acıyla duymaktadır çünkü kızı zorla kaçırmayı düşünmektedir. Kızı kaçırmanın çok kötü olduğunu, bunun vatanını yüzüstü bırakmaya, dertler içinde boğuşan Osmanlı'ya bir dert daha açmaya yol açacağını bilse de içten içe bunu arzulamaktadır. Ömer Seyfettin için "vatan, kahramanlık, fedakârlık" kavramlarıyla bağdaşan namus, kendi arzularını ülkenin ihtiyaçlarının önünde tutan, içten içe bütün sorumluluklarından uzaklaşmayı isteyen ve hiçbir fedakârlıkta bulunmayan subayda eksiktir. Onu bağlayan birtakım kayıtlar olmasa subay, bütün düşüncelerini derhal gerçekleştirecektir. Subay, namuslu olmak insanın elinde olduğu için kızı kaçırmak düşüncesinden vazgeçse de ahlakın temelinin onda olmadığının farkındadır. Örneğin eşkıya takibine memur olduğu halde kızla işleri "azıttıklarını" dillendirir (Seyfettin, 2009: 63). Ömer Seyfettin, burada hem bireysel hem toplumsal gereklilik olan ahlaka vurgu yapmaktadır. Erotik denilebilecek ifadelerle zihnen namusun "Yüksek Ökçeler" hikâyesindeki "meşru daire dışında bir kadın ile erkeğin münasebet içine girmesi” ilkesi aşılmaktadır: "Aman Yarabbi! Ya kalçalarl... Ben İstanbul'da hiç kalça güzelliğine dikkat etmemiştim. Eski sanat eserlerinden kalma bir granit heykel gibi... Taraçanın kenarına daima sağ kalçasını kabartarak dayanıyor, yün çoraplı güzel kalın bacaklarını, nihayet bulmaz milli çorabını örerken, uçları ince parmaklı, işten biraz esmerleşmiş kuvvetli pençelerini hep dürbünle seyrediyorum..." (Seyfettin, 2009: 64) yahut "Tahayyülü sırtımda sıcak ürpermeler gezdiren iri fırlak göğüslerini dar cepkeni taşıracakmış gibi sıkıyor." (Seyfettin, 2019: 65). Bir Bulgar kızının bir Türk subayını işinden böylesine alıkoyması, subayın toplum ahlakına yakışır biçimde davranmadığını gösterir. Ayrıca subayın Rada'ya bakışı da ahlaksızcadır. Dolayısıyla burada hem bireysel ahlak sınırları hem de toplumsal ahlak sınırları aşıımış olmaktadır.

Subay, namusluluk için gerekli olan "yalan söylememe" ilkesini de çiğnemiş̧ir: Hep odada oturmasına bir hastalık kulbu bulabilmek ve Bulgar kızı Rada'yı görebilmek için gündüzleri hep penceresi açık oturduğu 
halde çavuşa penceresini bir kere açtığını ve nezleden kurtulamadığını söylemiştir. Subayın, Manastır'a gitmeden önce kıza hediye göndermek için ev sahibini "çok mutaassıp" bulması da dikkat çekicidir. Ömer Seyfettin, durumu belirginleştirmek için karşıt karakterlerden yararlanmış ve ev sahibinin tarafında olduğunu hissettirmiştir. Ömer Seyfettin, subayın mutaassıp bulduğu ev sahibinin, aslında olması gerekeni yapmakta olduğunu ve toplum ahlakını korumaya çalıştığını mizahi bir unsur olan ironi yoluyla anlatmaktadır. "Nakarat", "Ömer Seyfettin için vatan ve kahramanlık duygularının, aşkla kıyaslanamayacak denli yüce olduğu" sonucunu vermektedir. Subay, Bulgar kızın nakaratında aslında i̇stanbul'u alacaklarını söylediğini öğrendiğinde kendini "şehvetten başka düşüncesi olmayan hayvan" olarak tanımlar (Seyfettin, 2009: 70) çünkü ahlaktan ve namustan yoksun bir şekilde davranmıştır. Ömer Seyfettin için ahlak ve onun bir değeri olarak namus, insanı insan yapan unsurdur: "Insanın hayvandan farkı ne? Mukaddes, yüce, yüksek bir fikre sahip olması değil mi?” (Seyfettin, 2009: 70). Namusun kahramanlık ve vatani bilinçle bağdaşan yönü; subay, ihtiyar meyhaneciye nakaratın anlamını sorduğunda açık bir şekilde görülmektedir: "'Hâşâ efendim' dedi, 'bizim köyümüzde bunu kimse söyleyemez! Biz bunu kabul etmeyiz. ...Buranın ahalisi hep namusludur." (Seyfettin, 2009: 74). Subayın lirik bir aşk güftesi gibi dinlediği bu nakaratı, meyhaneci dillendirmekten dahi çekinmektedir. Subayın nakaratın namusa ters olan tarafını ihtiyar söyleyene kadar bir türlü kavrayamaması ve onu çok müstehcen sanması mizahi bir unsur olup namusun sadece müstehcen karşıtı olmadığını, vatani bilince de bağlı olduğunu gözler önüne serer.

"Nakarat"In iki ana ve zıt unsuru; "aşk, şehvet" ve "vatan, kahramanlık”tır. Namus kavramı bu kavramların zıtlığı üzerinden işlenmiştir. Subay, kıza ne kadar aşk ve şehvet beslerse vatani görevini o kadar unutmaktadır. Bu aşk ve şehvet; subayın "Seni Seviyorum" anlamında anladığı "istanbul bizim olacak" nakaratını kızla tekrar etmesine, hatta ardından gelecek kimseler için bu nakaratı duvara kazımasına sebep olmuştur. Subayın ahlakı anlamak ve yaşamak yolundaki asıl handikabı, maddi şeylere duyduğu hevestir. Yani hikâye, daha da genel bir çerçeveden bakılacak olursa, maddiyat ve maneviyatın zıtığı etrafında kurgulanmıştır, denilebilir. Subay, erkânıharp olma hırsının vatan için değil; "çabuk terfi etmek, yüksek mevkilere geçmek, güzel i̇stanbul'da zevk ve eğlence içinde yaşamak, çok iyi yemek, çok iyi içmek, çok iyi giyinmek, zengin bir hanım avlamak, çabucacık paşa olmak, Avrupa'da ateşemiliterlikle keyif yetiştirerek ömür sürmek" olduğunu itiraf eder (Seyfettin, 2009: 71). Hakikatini ona öğretense, Bulgar kızı Rada, hatta onun kendi davası uğruna ölmeyi göze alabile- 
cek, komite olan papaz babasıdır. Subay, zulmüne uğradığı düşmanın ona ve milletine küfreden kızına âşık olarak namusun en büyük ilkesini çiğnemiş olmaktadır. Tayfun Barış (2016: 37), "Nakarat"ın amacını şu şekilde ifade etmiştir: "Zira genç bir Bulgar kızı, askerlikle hiçbir alâkası olmamasına rağmen, bir Türk zabitinden çok daha önce millî bir bilince varmış ve kendisine göre bir fikri ideal edinmiştir. Dolayısıyla Türklük için esas felâket iki ayrı millete mensup olan bu iki gencin aralarındaki zihniyet farkından kaynaklanmaktadır. Yazarımız da bu noktaya vurgu yapmak suretiyle okuyucularını uyarmakta ve Türk gençlerini millî şuur noktasında uyanık olmaya çağırmaktadır." Ömer Seyfettin, "Nakarat”taki bu uyanışı namus bilinciyle bağdaştırmış, dolayısıyla gençleri aynı zamanda namuslu olmaya da çağırmıştır. "Nakarat", namus kavramının özellikle toplumsal bilinçle olan bağı hususunda okuyucuya oldukça önemli mesajlar vermesiyle ve Ömer Seyfettin'in hikâyeciliğinden önemli ipuçları taşımasıyla dikkate değer bir hikâyedir.

\section{Sonuç}

Ömer Seyfettin'in "Yüksek Ökçeler" ve "Nakarat" adlı hikâyelerini ortak kılan unsurlar, mizah ve ahlaki bir değer olarak namustur. "Yüksek Ökçeler"in son derece mizahi tonu, "Nakarat"ta yerini kara mizaha bırakmaktadır. Ömer Seyfettin'in hikâyeciliğinde önemli bir yer tutan mizah; hikâyelerine kişiliğinin bir yansıması olarak girmiştir. Ömer Seyfettin mizahı kullanarak hikâyelerinde hem gülünçlük sağlamış hem de toplumu eleştirmiştir. Mizah, "Yüksek Ökçeler” hikâyesinde, yüksek ökçeler sembolüyle işlenmiş ve bu sembol, insanların arsız, hırsız ve namussuz oldukları gerçeğini örtmüştür. Dolayısıyla Ömer Seyfettin, doğrudan doğruya mizahi olarak değerlendirilen "Yüksek Ökçeler" hikâyesinde toplumda ahlaksızlığın ve namussuzluğun gittikçe artmasını da hicvetmiştir. "Nakarat" adlı hikâyede mizah; milli kimliğine küfreden Bulgar kızına âşık olan Türk subayı üzerinden, aşk, şehvet gibi maddi duygular ile vatani bilinç, kahramanlık gibi manevi duygular arasındaki zıtlıkla, ironik bir şekilde işlenmektedir. Ömer Seyfettin bu hikâyede ayrıca, vatan, kahramanlık gibi değerlerin aşk duygusundan çok daha yüce olduğunu savunmuştur. Namus, Ömer Seyfettin'in hikâyelerinde geniş bir yer tutmasıyla yazarın hikâyeciliğinde önemli bir unsurdur. Gerçek sanatçının fikirlerini eserlerinde işleyerek topluma aktardığına inanan Ömer Seyfettin, "Yüksek Ökçeler" hikâyesinde de "Nakarat" hikâyesinde de ahlaki bir değer olarak namusun ilkelerini yerine getirmeyen insanı eleştirmiş, mizah yoluyla devrine ayna tutmuş, bilhassa "Nakarat" hikâyesinde sosyal tenkit yaparak toplumu eğitme amacı gütmüştür. "Nakarat"ta Ömer Seyfettin, Türkleri milli uyanışa ve namuslu 
olmaya çağırmaktadır ve namus kavramını milli kimlikle örtüştürmektedir. Ömer Seyfettin'e göre namus kavramı, ideolojik bir bilinçle anlam kazanır ve namus, insanı insan yapması bakımından oldukça önemlidir. Ömer Seyfettin'in hikâyelerindeki mizah ve namus kavramları, onun toplum hakkındaki fikirlerine ve hikâyeciliğine ışık tutmalarıyla önemli bir yer taşımaktadır.

\section{Kaynakça}

Aktaş, Elif ve Yurt Uzuner, Serap (2017). "Çocuk Edebiyatı Açısından Ömer Seyfettin'in Hikâyelerinde "Çocuğa Göre" Olmayan Unsurlar". International Online Journal of Educational Sciences, 9(1): 207-223.

Alangu, Tahir (1968). Ülkücü Bir Yazarın Romanı. İstanbul: May Yayınları. Alay, Okan (2019). "Mizah Kavramı ve Mizahın Tarihsel Süreci”. Dil ve Edebiyat Dergisi, 116(808): 22-30.

Arşiv-1: Taha Toros Arşivi (Taha Toros, 001584544010, no: 23-24, 1983); İstanbul Şehir Üniversitesi Arşivi.

Arşiv-2: Taha Toros Arşivi (Taha Toros, 001584591010, no: 23-24, 1985); İstanbul Şehir Üniversitesi Arşivi.

Barış, Tayfun (2016). "Türk Edebiyatına Yansıyan Yönleriyle Türk Savaş Tarihinin Kara Bir Sayfası: Balkan Savaşları". Uluslararası Sosyal Araş tırmalar Dergisi, 9(42): 32-42.

Beyitoğlu, Yahya Kemal (2018). "ideal Bir Toplum Yaratmak: Ömer Seyfettin'in Hikâyelerinde Toplumsal Eleştiri”. ÇÜTAD Çukurova Üniversitesi Türkoloji Araştırmaları Dergisi, 3(1): 26-54.

Çetinkaya, Gülnaz (2006). Gırgır Dergisinin Türk Halkbilimi Açısından incelenmesi. Yüksek Lisans Tezi. Ankara: Hacettepe Üniversitesi Sosyal Bilimler Enstitüsü.

Er, Rabia Nesrin (2019). "Çocukların Sosyal Gelişiminde Edebiyatın Rolü”. AVRASYA Uluslararası Araştırmalar Dergisi, 7(17): 199-219.

Galin, Müge (1989). Turkish Sampler. Writings for All Readers. Indiana: Indiana University.

Güneş, Mehmet (2011). "XX. Yüzyılın Başlarında Balkanlardaki Siyasî ve Etnik Çatışmaların Ömer Seyfettin'in Hikâyelerine Yansıması”. Türklük Bilimi Araştırmaları, 29: 163-187.

Kanter, Beyhan (2013). "Ömer Seyfettin Hikâyelerinin Kurucu Unsurları: Tarih ve Dil”. Yeni Türk Edebiyatı Araştırmaları, 5(10): 99-113. 
Koçak, Ahmet (2015). "Savaşın Gölgesinde Yazılan Hikâyeler: Ömer Seyfettin'in Hikâyelerinde Savaşın Yansımaları”. Çanakkale Araştırmaları Türk Yıllığı, 13(18): 637-656.

Narlı, Mehmet (2007). “Ömer Seyfettin'den Cemal Şakar'a Öykü ve İroni”. ilmî Araştırmalar Dergisi, 24: 103-115.

Önertoy, Olcay (1972). “Küçük Hikâye Yazarı Olarak Ömer Seyfettin”. Türkoloji Dergisi, 4(1): 137-145.

Özsaray, Yunus Emre (2018). “Ömer Seyfettin'de Toplum Eğitimi: Hikâyelerin Değer Değişimi Açısından incelenmesi”. Türk Dili ve Edebiyatı Dergisi, 58(2): 399-417.

Seyfettin, Ömer (2009). Bütün Hikâyeleri 6. İstanbul: Üç Harf Yayıncılık.

Şengül, Abdullah (2001). "Ömer Seyfettin'de Millî Kimlik”. Sosyal Bilimler Dergisi, 3(1): 1-14.

Tanrıbuyurdu, Erol (2007). "Temel Fıkralarında Toplumsal Eleştiri". Milli Folklor, 19(75): 104-107.

Tulgar, Yıldız (2019). Ömer Seyfettin'in Hikâyelerindeki Halkbilimsel Unsurların Tespiti ve Incelenmesi. Yüksek Lisans Tezi. İstanbul: İstanbul Üniversitesi Sosyal Bilimler Enstitüsü.

URL-1: "Güncel Türkçe Sözlük”. https://sozluk.gov.tr/ (Erişim: 29.04.2020) 